\title{
Climate Change Adaptation and Community Development in Port Harcourt, Nigeria
}

\author{
Julie Greenwalt, Michael Dede, Ibinabo Johnson, Prince Nosa, \\ Abi Precious, and Barbara Summers
}

\section{Contents}

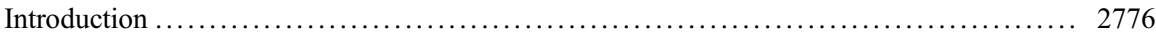

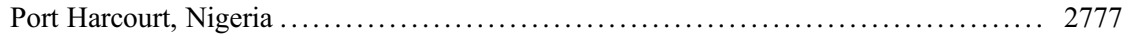

Communities First: Effective Community-Led and Data-Driven Change ............... 2779

Community Mapping and Data ......................................... 2780

Documenting Sanitation and Exacerbating Conditions ....................... 2783

Data and Media Advocacy ............................................. 2787

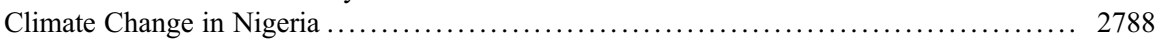

Climate Change Adaptation: Voices from the Community and Global Recommendations ... 2791

Global Recommendations for Advancing Adaptation ............................ 2791

Port Harcourt in Focus: Climate Change Adaptation Awareness and Action ........... 2792

Climate Change Impacts Observed ......................................... 2795

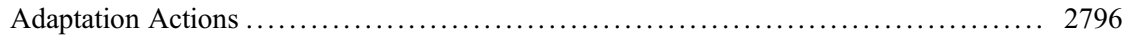

Proposed Adaptation Solutions .......................................... 2798

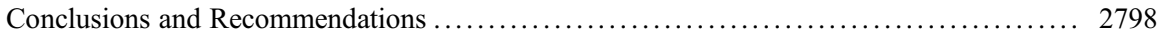

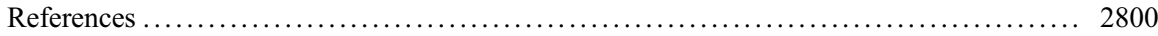

This chapter was previously published non-open access with exclusive rights reserved by the Publisher. It has been changed retrospectively to open access under a CC BY 4.0 license and the copyright holder is "The Author(s)". For further details, please see the license information at the end of the chapter.

\section{J. Greenwalt $(\bowtie)$}

Go Green for Climate, Amsterdam, Netherlands

e-mail: julie@gogreenforclimate.com

M. Dede $\cdot$ I. Johnson $\cdot$ P. Nosa $\cdot$ A. Precious

Chicoco Collective, Port Harcourt, Nigeria

B. Summers

CMAP, Port Harcourt, Nigeria

e-mail: barbara@cmapping.net 


\section{Abstract}

Port Harcourt, Nigeria, as with many cities in Africa, is already experiencing impacts from climate change while also facing development challenges and compounding vulnerabilities. There is often a gap between the adaptation recommendations of academia and international organizations and the conditions needed to achieve these recommendations given the realities on the ground in cities with vulnerable populations, pressing challenges, and minimal capacity. This gap can make it difficult to translate theoretically persuasive plans and guidance into practically sustainable actions. This chapter builds on the experience of CMAP, a Port Harcourt-based NGO leading participatory mapping, community media, and public space design programs in the city's informal waterfront settlements. Drawing on the perspectives of Chicoco Collective, the youth-led volunteer network which CMAP supports, and the datasets that they have built, the chapter explores local awareness and skills for climate change adaptation. This chapter concludes with recommendations relevant for Port Harcourt and similar African cities to build on such local skills and experiences and advocates for a partnership-based approach that brings together adaptation professionals and community-based actors for more effective critical analysis of local conditions and prioritization of actions to meet the development and climate change needs of local communities.

\section{Keywords}

Community development $\cdot$ Port Harcourt $\cdot$ Nigeria $\cdot$ Flooding $\cdot$ Community data Awareness raising $\cdot$ Informal settlements

\section{Introduction}

There is growing global awareness and urgency about the need to accelerate action to adapt to climate change. Many cities and local communities, especially in Africa, are already experiencing the impacts of climate change, and risks and vulnerabilities are increasing. This chapter focuses on Port Harcourt, Nigeria, which is a secondary city in the most populous country in Africa and the oil capital of Nigeria. The chapter will share data and information gathered by CMAP, a local NGO, and Chicoco Collective, the youth-led volunteer network that it supports, to explore the risks and vulnerabilities in Port Harcourt, as well as the ongoing work of CMAP and the perspective of local communities, to identify some of the key challenges and to propose recommendations for how Port Harcourt and similar African cities could accelerate action on climate change.

The chapter also explores the gap between the adaptation recommendations of academia and international organizations and the conditions needed to achieve these recommendations given the realities on the ground in cities with vulnerable populations, pressing challenges, and minimal capacity. This gap can make it 
difficult to translate theoretically persuasive plans and guidance into practically sustainable actions. However, a partnership-based approach that brings together adaptation professionals and community-based actors for more effective critical analysis of local conditions and prioritization of actions can help to advance both the development and climate change adaptation needs of local communities.

This chapter presents findings from focus groups, mapping, surveys, and transect walks undertaken by CMAP and Chicoco Collective related to community development, vulnerability, and climate change awareness. It also provides a brief introduction to Port Harcourt, climate change in Nigeria, and a brief review of some of the latest literature and recommendations produced at the global level on adaptation to climate change in cities, Africa, and informal settlements.

\section{Port Harcourt, Nigeria}

Port Harcourt is the capital of Rivers State and is located in the Niger Delta region. The city lies at the mouth of the River Bonny. It is located approximately $25 \mathrm{~km}$ from the Atlantic Ocean and is situated between the Dockyard creek/Bonny River and the Amadi creek. It lies at an average altitude of about $12 \mathrm{~m}$ above mean sea level, although the waterfront communities tend to be below $4 \mathrm{~m}$ (Fig. 1).

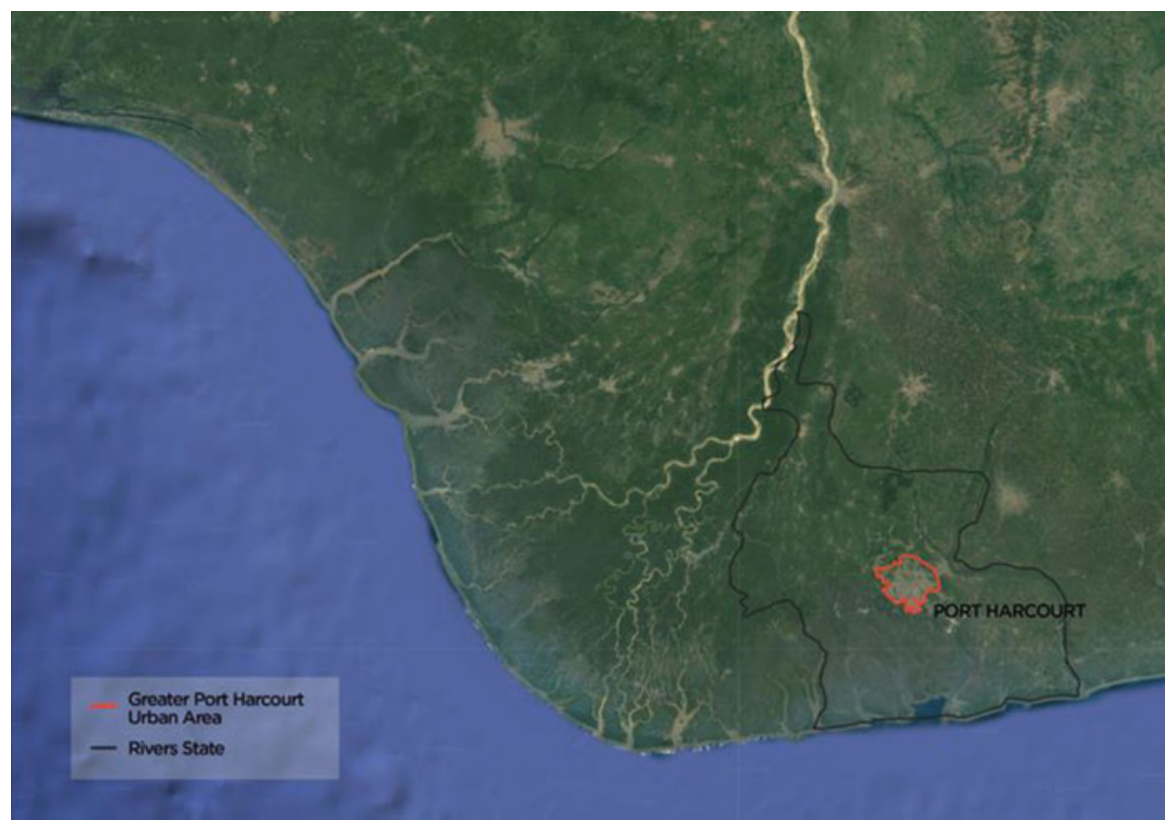

Fig. 1 Map of the Niger Delta highlighting Port Harcourt's location $25 \mathrm{~km}$ inland from the Atlantic Ocean (created by CMAP in March 2020 using QGIS and data from Rivers State Office of the Surveyor General) 
Port Harcourt was founded in 1912 during the colonial era as a railroad terminus and deep-water port for exporting coal, then later, oil and gas, after their discovery in the late $1950 \mathrm{~s}$ in the Niger Delta. The oil and gas sector continues to dominate the local formal economy. However, despite the economic wealth generated in the region, many people in the city and state live in impoverished conditions. IMFimposed structural adjustment in the 1980s and 1990s saw Nigerian cities such as Port Harcourt simultaneously grow and physically deteriorate. Even as they absorbed newcomers, they often lacked the resources to provide appropriate infrastructure and services to growing populations. With an economy so closely connected to resource extraction, long term plans are vulnerable to disruption by oil and gas-market downturns, as well as changes in state government. Historically, a drop in oil prices has corresponded to a shortage of resources for housing, water supply, security, or waste management in Port Harcourt and is often linked with the proliferation of informal settlements (Bloch et al. 2015). A series of abandoned Port Harcourt master plans and infrastructure projects, most notably the monorail, which starts and ends abruptly and has never been used, are testament to the absence of sustained urban planning and action as a result of low economic and political investment.

Despite its current ranking as one of the largest economies in Africa, Nigeria has failed to translate growth in output into an increase in formal employment, and this failure has resulted in significant underemployment. This is an even greater challenge for the country's growing share of youth. Fifty-five percent of the population is under the age of 20 (World Bank 2016). This nationwide trend is evidenced in employment rates in Port Harcourt where not only has youth unemployment increased, but is coupled with significant underemployment and a lack of productive opportunities for young workers. For many youth, participation in the illegal/informal crude oil refining process in the creeks around the city is seen as one of the few but most lucrative - options in the local economy. Further exacerbating the issues, the city once known as the Garden City is now characterized by degradation of waterways, soil, and air largely due to the oil and gas industry (both legal and illegal).

Nigeria is a federal state with much of the governance power resting in state governments which have ministries for environment, urban development, education, etc. Despite this decentralized governance system, active city governments are largely nonexistent, and state governments have primacy over physical development in urban areas. This is the case in Port Harcourt.

The city of Port Harcourt has an estimated population of over 1.8 million, making it the sixth largest city in Nigeria and the largest in the South-South region (OECD/ SWAC 2020). The climate is tropical monsoon with an annual mean maximum temperature $30.9^{\circ} \mathrm{C}$ and mean minimum temperature $22.6^{\circ} \mathrm{C}$ (www.wmo.int).

As noted in the 2009 Max Lock Centre study by Theis et al., spontaneous and uncontrolled physical growth driven by rapid urbanization in Port Harcourt over the last several decades has increased the settlement of the areas alongside swamps in the waterfront. Faced with high-cost inner-city rentals and a shortage of housing, many new urban dwellers are forced to settle in high-risk neighborhoods exposed to 
flooding and the adverse effects of climate change. These waterfront communities are now the largest informal settlements in the city, with some population estimates of over 480,000 people (Theis et al. 2009). While they have varying levels of development, with little to no government intervention or service provision, they can be characterized as lacking in many basic services including sanitation, water, and waste disposal. These communities also regularly face the threat of forced eviction with several large-scale demolitions taking place in 2009, 2012, and 2016.

\section{Communities First: Effective Community-Led and Data-Driven Change}

Collaborative Media Advocacy Platform (CMAP) has been working with residents of informal waterfront communities in Port Harcourt for over 10 years. CMAP began as an informal association motivated by building both local and global awareness of, and halting, massive forced evictions in waterfront communities. The project's animating impulse was the response of community members to the camera of the organization's now-project director when he found himself in the middle of a largescale forced eviction. In the middle of the demolition, residents rallied around the camera, protecting it from the police and directing what it filmed.

In 2009, the then Governor of Rivers State announced the planned demolition of all the city's waterfront settlements. These settlements were not represented on municipal maps. They featured in the city's development plan only as undifferentiated zones marked for "clearance" through "major relocations." The resultant forced evictions and demolitions triggered not only widespread displacement, but also a conflict that threatened to become militant. In response, a group of local activists and international campaign organizations started to support mobilization of these marginalized waterfront communities, making visible the violence and disregard of state agencies through documentary photography, film, and recorded testimonies.

Following initial campaigning and legal advocacy work, there was a systematic broadening of engagement with different forms of representation - from the cinematic to the cartographic, from the voice on the street to the voice on the airwaves, and from architectural design to legal representation - and a strategic exploration of how they could be layered to support the struggle of Port Harcourt's waterfront settlements to be seen and heard. After several years of ad hoc activities, programs were solidified into the Human City Project, led by CMAP and a local communityregistered trust. The project's programs - Chicoco Cinema, Chicoco Radio, Chicoco Sound, Chicoco Maps, and soon Chicoco Solar - are the focus of the Chicoco Collective. In its over 9 years of work, the project has established highly trained community mapping and media teams, including reporters, writers, presenters, broadcasters, filmmakers, photographers, actors, musicians, surveyors, and technical producers, with the capacity to manage a community radio and music studio.

The Chicoco Maps program, which launched as a direct response to communities not being recognized on any map or in official statistics, focuses on building the 


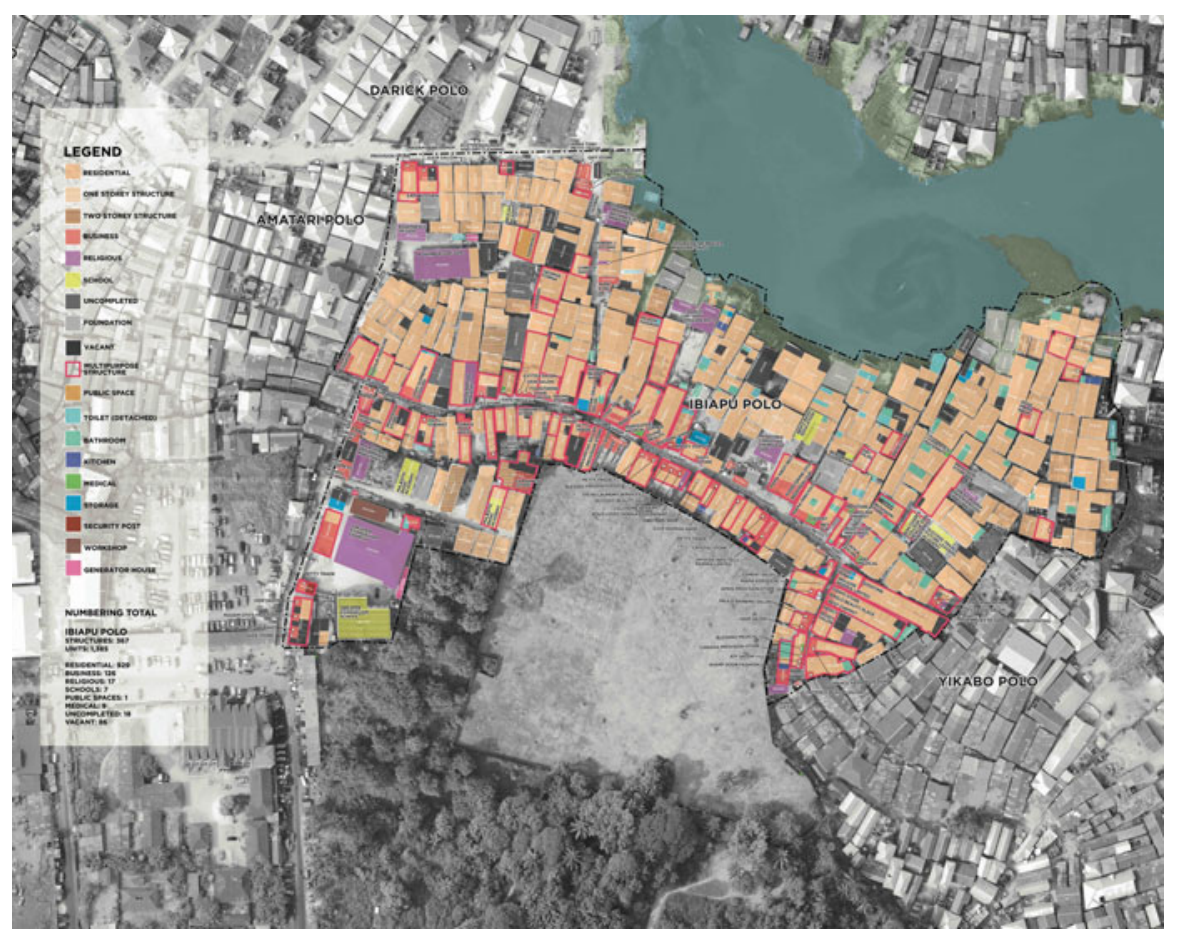

Fig. 2 Household unit map of Ibiapu Polo Waterfront Community (CMAP 2018)

capacity of young waterfront residents to put their communities on the map, capture the information to tell their story on their terms, and generate the necessary data to negotiate with government authorities. Over the past 6 years, the volunteer community cartographers have created base maps of six waterfront communities and, for three of those communities, have developed the most thorough dataset on any community in the greater Port Harcourt area. An example of one of the community maps can be seen below which details structures and land use (Fig 2).

Their work has involved indexing every building, as well as conducting household surveys, gathering detailed community-level data on population, land use, employment, health, and service provision, among others. This data is fed into an encounter and exchange program in which civil society, government representatives, and community members are brought together in solution-focused discussions facilitated by project participants around their data and map outputs in each community.

\section{Community Mapping and Data}

The Chicoco Mapping team carried out detailed demographic and structure/infrastructure surveying of three waterfront communities. The team was able to survey 
Table 1 Demographics of three waterfront communities in Port Harcourt: Ibiapu, Darick, and Amatari Polos (CMAP 2018)

\begin{tabular}{l|l|l|l}
\hline & Ibiapu Polo & Darick Polo & Amatari Polo \\
\hline Population & 4,079 & 1,922 & 1,846 \\
\hline Number of households & 969 & 447 & 504 \\
\hline Population density $\left(\mathrm{ppl} / \mathrm{km}^{2}\right)$ & 73,833 & 35,900 & 67,000 \\
\hline Number of businesses & 126 & 69 & 97 \\
\hline
\end{tabular}

$77-80 \%$ of households in each community, which gave a representative number of responses to extrapolate total population as well as to understand the major trends in the community. The following overview statistics of Ibiapu Polo, Darick Polo, and Amatari Polo communities can be seen in Table 1 .

These communities share similar topographical characteristics with other waterfront communities throughout the city, being 10-15 m below the rest of the city on land reclaimed from mangroves. Amatari Polo is the oldest of the three, settled over 60 years ago. Ibiapu Polo is approximately 40 years old, while Darick Polo is less than 20 years old and is the only community that has been sand-filled. The others are built on "chicoco" mud, extracted from the mangroves. Despite the majority of residents having lived in their communities for 5 years or longer, households predominately reported having only informal or community-granted documentation of rent or ownership.

All three communities have a young population, with over $50 \%$ of residents under the age of 25 . Unemployment rates were reported as $10-12 \%$, but it is likely that actual unemployment rates are higher, with many people reporting self-employed and not employed full-time. These waterfront communities are all managed by an Okrikan system of community leadership led by an elected community chairman and supported by a range of committee members including a woman leader, youth leader, sanitation chairman, light chairman, etc.

While the community mapping project was initially focused on collecting data for preventing forced evictions or negotiating with the government on security of tenure or service provision, it is a useful basis for understanding some of the existing climate change impacts or highlighting potential vulnerabilities. For instance, the household surveys found that over half of households reported that flooding after a rainfall event restricts their movement. Furthermore, 29\% of households reported that they always have to wait a while after it rains before they can leave their home. The chart below highlights the impacts of flooding on individual households (Fig. 3).

Infrastructure networks including roads and pathways, electrical, water, and waste networks have also been documented in detail in the mapping process. This is often the first time community scale infrastructures have been documented. This aggregation of infrastructure often highlights the ad hoc manner in which drainage is implemented in the community and between bordering communities when the various community data are collated. For example, the map below indicates that the drainage network in Ibiapu Polo, one of the neighborhoods intensively mapped and surveyed by the Chicoco team, is not integrated and few of its channels are 
Fig. 3 Households in Ibiapu, Darick, and Amatari Polo reporting the ability to leave their home after a rainfall event. The response options were that yes, they can always leave their home; yes, they sometimes have to wait; or no, they always have to wait for flooding to recede (CMAP 2018)
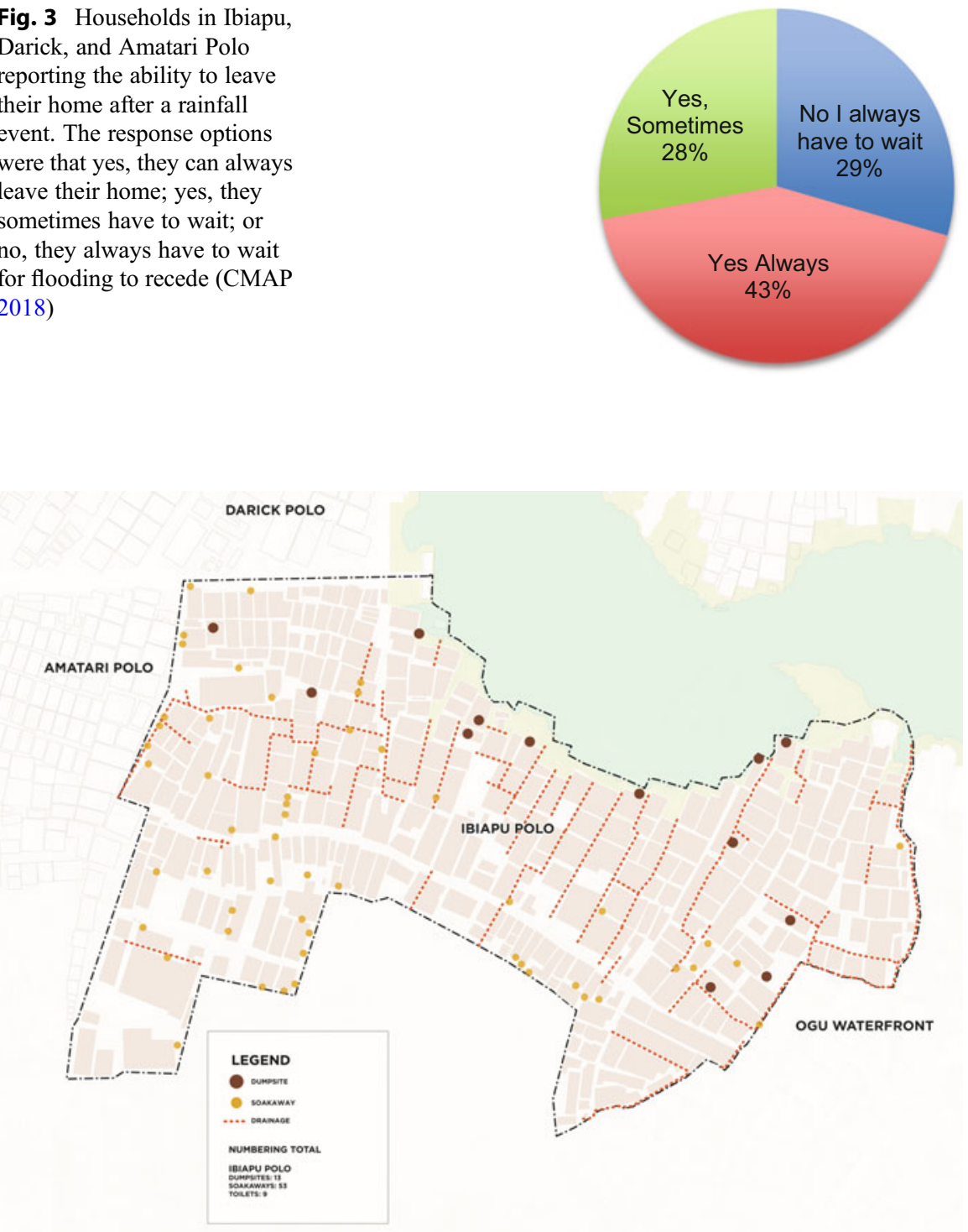

Fig. 4 Waste network map of Ibiapu Polo Waterfront Community, CMAP (2018)

ultimately connected to the larger network. These maps can serve as a base for understanding flooding bottlenecks and planning for improvements in each community. Insights into impacts of the poor drainage system and flooding are deepened by the household survey. Between $60 \%$ and $78 \%$ of households reported that drainage was one of the major problems facing their household (Fig. 4). 
Another major problem raised by residents in the household survey was access to drinking water because the majority of households reported needing more than one source of drinking water. The two most significant sources of water reported are sachet water (i.e., water sold in small, sealed plastic bags) and private boreholes/taps outside their house. Less than one third of all households surveyed had access to piped water within their home.

Other issues raised by households in the survey included sewage leakage/lack of toilet facilities and management of solid waste. While these issues may not directly link to impacts of climate change at this time, they are likely to continue to exacerbate the impacts of climate change in these already vulnerable communities.

\section{Documenting Sanitation and Exacerbating Conditions}

There have been impacts at the community scale of the mapping work, but more significantly a shift in the citywide development dialogue. An African Development Bank-funded state water and sanitation services project in Port Harcourt claimed to be planning to reach 1.5 million people in Port Harcourt with improved WASH services. Yet, no waterfront communities or informal settlements were included in the initial designs. Data gathered by the Chicoco Maps team demonstrated the impossibility of reaching that many people unless the informal spaces of the city were included. In response, the project design was revised to include the city's waterfront settlements. Subsequently, as part of this larger project, in 2017, the mapping team led the data collection component of the World Bank-funded study "Technical Assistance to Fecal Sludge Management (FSM) Services in Port Harcourt, Nigeria."

While the data collection of this FSM study covered a range of urban morphologies, socio-economic conditions, and geographic locations, the project included a focus on low-income communities in Port Harcourt, and therefore a significant focus on waterfront communities. While the attention was primarily on documenting sanitation conditions and service provision, a number of climate-change-related risks and coping mechanisms were documented throughout the data collection process.

Both quantitative and qualitative research methods were employed to explore FSM practices along the entire service chain of collection, transport, treatment, and safe end use or disposal (World Bank 2017a). One of the data collection instruments used was a transect walk, during which enumerators walked through a community with several local residents to identify risks to public health, particularly with regard to the presence of fecal material and solid waste, and the proximity of these wastes to drainage channels and water resources. The World Bank defined objective was to observe environmental and public health risks along specified routes throughout the community.

The tool was revised by the community mapping team to fit the local context with revised survey questions and local terminology and piloted in two waterfront communities. The transect walk process was designed so that information on 


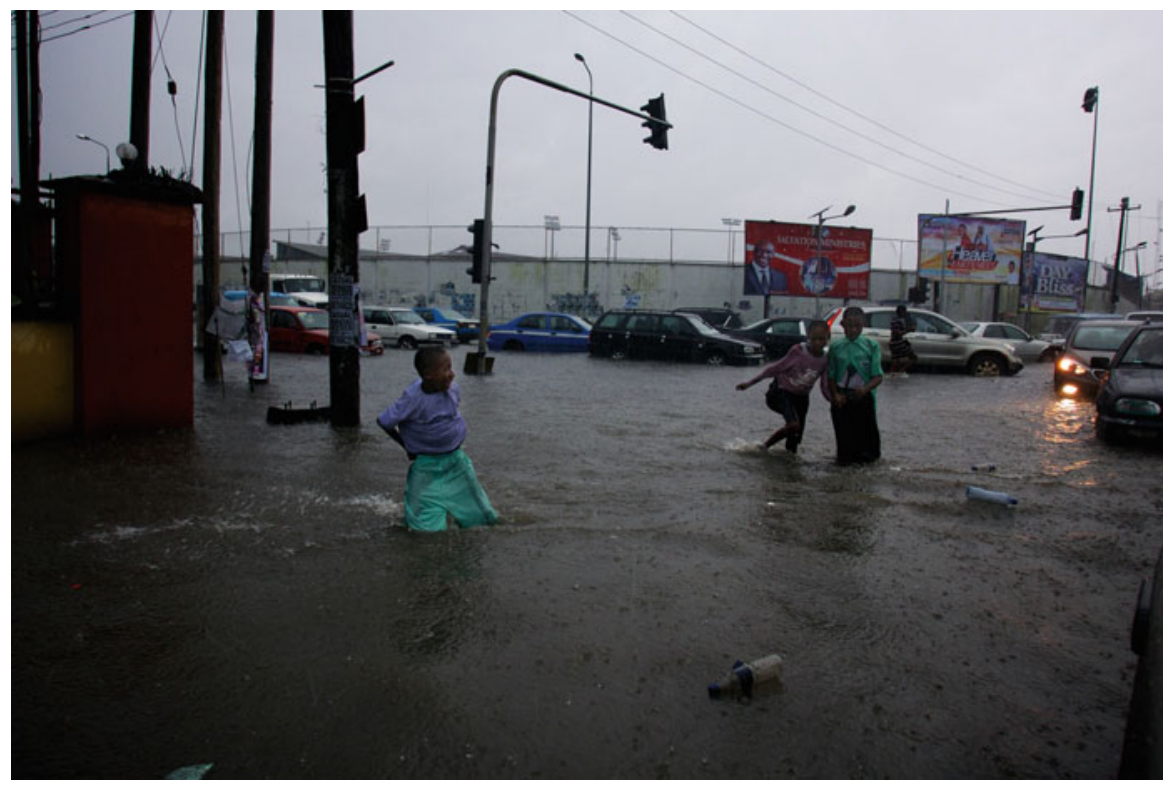

Fig. 5 A flash flood in Port Harcourt Old Town during rainy season (photo credit CMAP 2016). (Permission obtained)

community characteristics, observed risks, and an estimate of how frequently these risks occur could be documented for each route and supplemented with GPS points and photo documentation. Observed risks were scored on a scale of " 1 to 5 ," with a score of " 5 " denoting a particularly high risk.

Moreover, transect walks were helpful in: identifying and explaining the cause and effect of relationships among water uses, wastewater treatment, and sanitation conditions; identifying major problems and possibilities perceived by community members in relation to features or areas along the transect; providing an understanding of local technology and practices; and helping to triangulate and/or validate data collected through other tools.

Of the mix of 15 low-income informal settlements, middle-income neighborhoods, and high-income gated communities documented through transect walks, $73 \%$ experienced persistent flooding as a result of heavy rainfall and/or high tide (World Bank 2017a) (Fig. 5).

Furthermore, high risks were found to be more prevalent in low-income communities than middle- or high-income communities. Observed risks in these areas included unofficial dumpsites containing both solid and fecal wastes, pit latrines emptying into open drains, and evidence of open defecation. Low-income communities received a "high risk" rating of " 4 " or "5" for $75.8 \%$ of the observed conditions. In comparison, middle- and high-income communities received a high-risk rating for only $17.3 \%$ of the observed conditions (World Bank 2017a) (Figs. 6 and 7). 


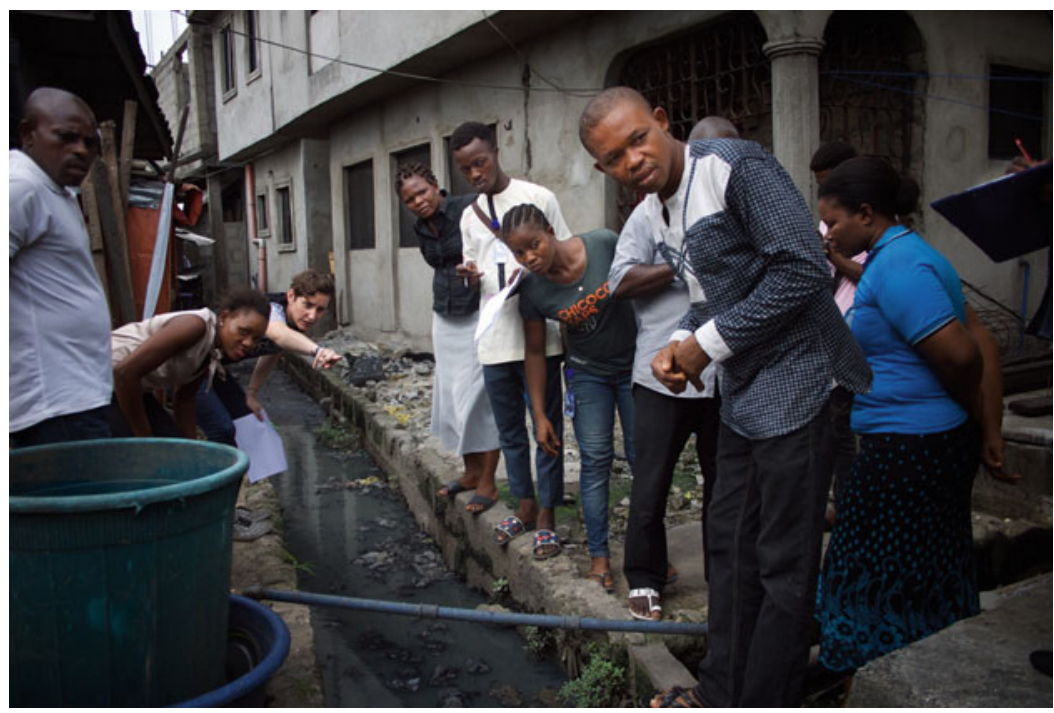

Fig. 6 The Chicoco mapping team conducting transect walks with community members to observe and record sanitation conditions in Tonipriama Ama Waterfront (photo credit CMAP 2017). (Permission obtained)

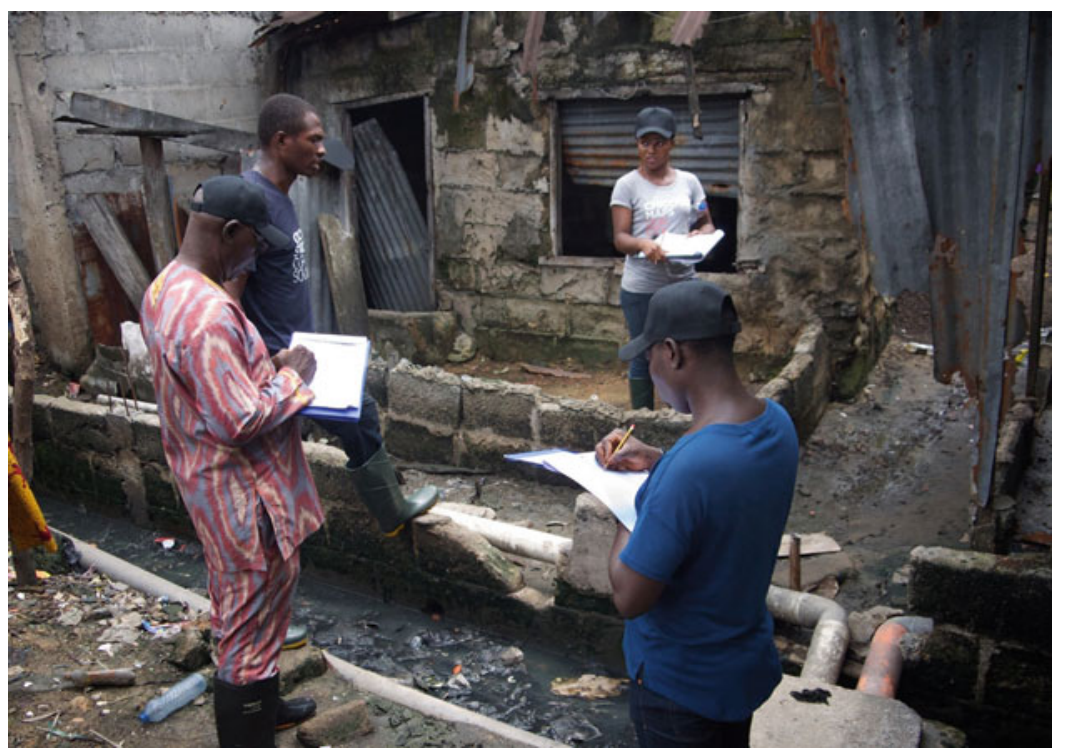

Fig. 7 The Chicoco mapping team conducting transect walks with community members to observe and record sanitation conditions in Baptist Waterfront (photo credit CMAP 2017). (Permission obtained) 
The community team also received significant training on facilitating focus group discussions and developed a comprehensive questionnaire to gather qualitative data to compliment, validate, and/or challenge responses reported in the household survey. Information obtained from these discussions provided insight into household and community practices, service levels, and perceptions of past efforts to improve FSM services.

A focus group discussion was conducted at all 15 transect walk sites. Some focus group discussions were gender-specific. This was done because in mixed-gender sessions, men frequently dominated the discussions. Some men-only sessions were also held. Findings from these community focus group discussions stressed flooding challenges in the communities and informal methods being used to cope. Respondents in several communities mentioned that they themselves or others in the community were using nets or palm fronds to try to keep the solid waste and other debris that comes with floodwaters out of their homes. In three of the waterfront communities, it was mentioned that the community constructed a barrier, in some cases a metal plate or berm made of solid waste, along the riverbank to prevent flooding from seasonal high tides (seen below in Fig. 8) (World Bank 2017a).

Through the discussions, it was further revealed that flooding issues in waterfront communities were from the river and its high tide, as well as from drainage issues from upland areas and in the community. One respondent emphasized that, during rainy season, nets and barriers are removed to allow for waste to flow into the river (seen below in Fig. 9). A number of people also mentioned it was common practice in their community for people to use sticks or brooms to push the stagnant water and waste back out to the river after a rainfall (Fig. 9).

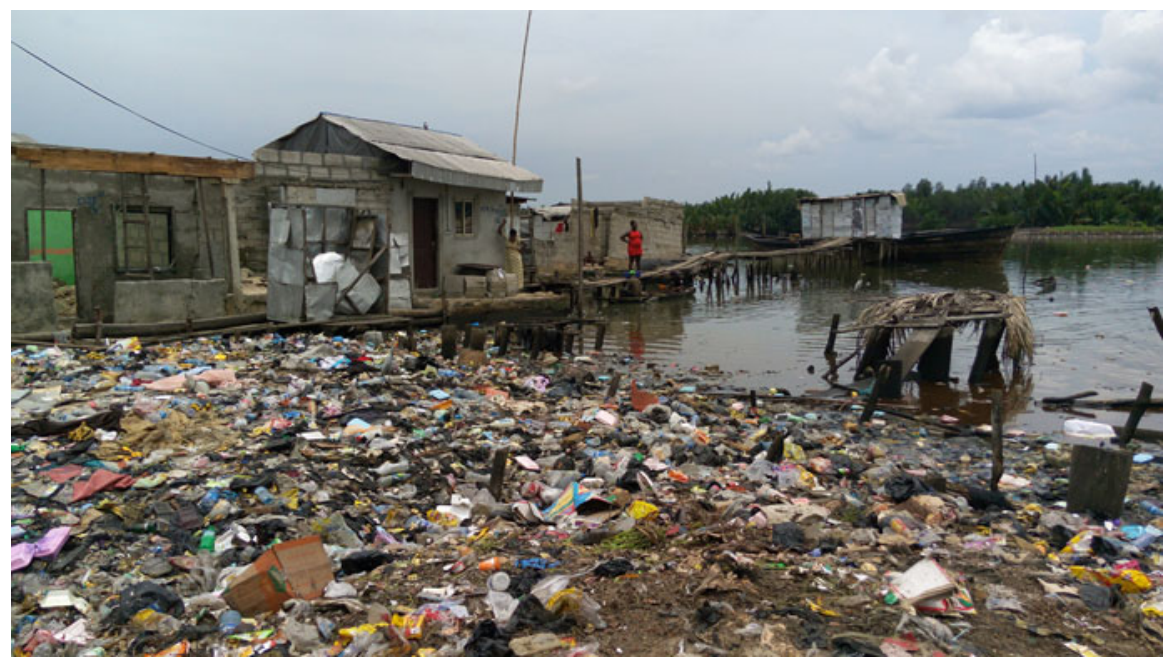

Fig. 8 A solid waste berm being created along the waterfront in Afikpo waterfront community (photo credit CMAP 2017) 
Fig. 9 Nets installed in Baptist waterfront community to protect from waste flowing back into the community (photo credit CMAP 2017)

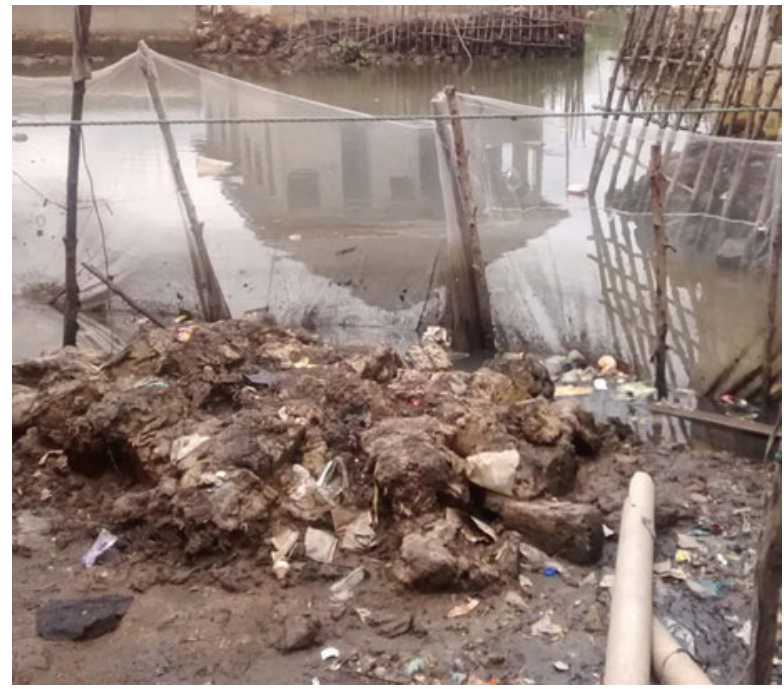

These focus group responses on flooding and their associated sanitation risks are supported by the findings of the Shit/Excreta Flow Diagram (SFD) created for this FSM project, which highlighted that other than the $13 \%$ of fecal sludge that remains unemptied in soak pits, there is no existing treatment of fecal sludge in low income areas of Port Harcourt, and it is directly entering the environment (World Bank 2017b).

\section{Data and Media Advocacy}

One of the unique aspects of the Chicoco Collective is that it brings together mapping and data collection with a range of advocacy platforms. The community mapping team has worked to analyze their data and has developed presentations to help the community and broader stakeholders think about how to best use the information to improve their community. In Ibiapu Polo, for example, the team was able to tally up all of the daily household expenses on drinking water into a yearly cost for the community. This totaled over 18 million Naira (approximately USD 50,000). Working with the community leadership, the cohort developed a proposal that is now being used by the community. The proposal seeks support to bring together these resources at a community level to implement a solar-powered public borehole, which is estimated to cost around seven million Naira, to serve the entire neighborhood's potable water needs.

A group of community mappers and journalists have built pilot air quality monitoring devices to document air quality conditions throughout the city. While their homemade devices do not yet yield data of sufficient accuracy or compositional detail to support rigorous analysis, their data does evidence alarming air conditions and reveals telling temporal and spatial pollution patterns. A team of campaigning 
citizen scientists has been working on how to use the data to create community awareness of air quality issues and is developing a citywide campaign. They have been able to further support this work through audiovisual documentation of illegal oil refining activities and their impacts on air quality, as well as interviews with community members and government representatives, including the then Rivers State Commissioner for environment.

These themes have also come together powerfully in other cultural and communicational forms, including as issues addressed through an original radio drama series "Angala Community," set in a fictional waterfront community. The most recent season of the radio drama, which will be aired citywide on partner stations, is focused on the gendered dynamics of waterfront communities, with an emphasis on sanitation and environmental conditions, including air quality. Numerous radio programs have been written, recorded, and produced by the community mapping and media teams addressing environmental issues in waterfront communities. One program in particular investigated the causes of flooding in the community, exploring the consistent blockage of drains and creeks with solid waste and the construction of unapproved buildings on waterways. This is an issue worsening rapidly as the waterfronts densify and expand into the mangroves, further compromising the capacity of these ecosystems to maintain hydrological balance, further undermining local livelihoods, and exacerbating entrenched economic and environmental inequalities.

The Chicoco Collective deploys a range of creative research, outreach, and engagement methods to bring climate-change-related issues to the forefront of community concern and broader popular conversation. Chicoco Cinema has used an inflatable pop-up movie theatre to raise awareness and keep local communities in the picture, increasing the accessibility of the discourse. The Chicoco Band, which includes a number of mappers, is currently working on their own cover of the wellknown Nigerian artist, Fela Kuti's, "Water No Get Enemy" to address the current and looming issues of access to potable water in their waterfront communities and the country. Music can be a powerful medium of movement-building and a critical way of translating research findings into adaptation action.

The Chicoco team has established a program for prioritizing focal areas for their work each year. Focal issues have included housing, gender dynamics, and most recently, climate change. These issues are discussed through weekly sessions: "Bringing It Home: local impacts of global issues." These sessions focus on cohort-led research and discussion to understand the global context of the issues and how they can be contextualized in Nigeria and in their communities. CMAP has supported these research efforts by connecting participants with area specialists and staging expert-led workshops and trainings. Climate change has been a sustained focus of CMAP's engagement and capacity-building programs since 2017.

\section{Climate Change in Nigeria}

Climate change is a global problem, but the effects vary from place to place, based on different climate change threats. According to the IPCC Fifth Assessment Report (AR5), the extent of climate change effects on individual regions will vary over time 
based on different socio-economic and ecological systems for mitigation and adaptation (2014a). The same assessment stated that Africa is one of the most vulnerable continents to climate change (2014a). This vulnerability of Africa to climate change is driven by several factors of which weak/poor adaptation capacity is one (Ofoegbu and Chirwa 2019). Other studies revealed that the vulnerability of Africa can also be attributed to inadequate access to climate data, institutions, finance resources, and poverty (Ojomo et al. 2015).

Nigeria signed the 2015 Paris Agreement on September 22, 2016 and ratified it on May 6, 2017. Nigeria subsequently developed its nationally determined contributions (NDCs) and submitted it in May 2017. The NDC includes a section on adaptation but focuses primarily on mitigation actions. Nigeria has not submitted a National Adaptation Plan to the UNFCCC; however, it does have a National Adaptation Strategy and Plan for Action which was developed in 2011. This strategy suggests that large urban areas, including Port Harcourt, should develop and implement their own climate change adaptation plans. However, one has not yet been developed for the city.

In order to meet the required implementation of the stipulated provisions under the climate conventions, the department of climate change unit in the Federal Ministry of Environment was created to handle national climate initiatives (Nigerian Conservation Foundation 2008).

In 2003, upon realizing the need to produce observable information on climate change, the Nigerian Meteorological Agency (NIMET) was created, with a department for the development and delivery of climate information.

The majority of analysis on the potential impacts of climate change has been done at the national level. However, in some cases there is evidence of specific impacts in Port Harcourt, Rivers State, and/or the Niger Delta.

Increase in temperature is cited by several sources, with projections that Nigeria may experience as much as $2.5-4.5^{\circ} \mathrm{C}$ by 2100 (Akande et al. 2017; Odjugo 2010; FME 2014). Variability in rainfall and the potential for the number of rainy days to decrease throughout the country and around $14 \%$ in the Niger-Delta coastal areas has been observed (BNRCC 2011; Odjugo 2005). While the number of rainy days may be decreasing, the frequency and magnitude of wind and rainstorms is increasing (Odjugo 2009).

The rise in sea level and flooding, especially in coastal regions like the Niger Delta, is another major concern (Matemilola 2019; Akande et al. 2017; Duru and Emetumah 2016, 2; Ebele and Emodi 2016, 7; FME 2014, 31; Odemerho 2014). This also impacts agriculture and provision of water due to salt-water intrusion (Odjugo 2010).

Frequent droughts, as the result of climate change, although mostly in the northern part of Nigeria, also have a negative impact on agricultural production and water security (Dioha and Emodi 2018; Elisha et al. 2017; Amanchukwu et al. 2015). Given some of the supply chain connections between Port Harcourt and the north of Nigeria, the impacts may still be felt by residents in Port Harcourt even if the impacts are not projected to take place in the Delta region.

There is some evidence that excessive heat, water stress, and air pollution will have an impact on health in Nigeria, especially in terms of water-related diseases 
(diarrhea, cholera, and skin diseases), respiratory diseases, exhaustion, skin cancer, and cataract according to one source (Odjugo 2010). Another study found that the four diseases most likely to be exacerbated by climate change in Nigeria are cholera, meningitis, malaria, and pneumonia (Omoruyi and Kunle 2012). A WHO report on climate change and health noted in the country profile on Nigeria that its "peculiarity as one of the leading exporter[s] of oil in Africa, faces [it with] the challenge of balancing global energy demands with the need to address climate and environmental considerations" (WHO 2015).

In Nigeria, the Federal Ministry of Environment defines vulnerability as the element of sensitivity to climate change that relates to how ready a specific system is to respond to changes in the climate, whereas exposure refers to the extent of climate stress to which a particular unit or system is exposed or the presence of people, livelihoods, species, environmental functions, services and resources, infrastructure, or economic, social or cultural assets in places and settings that could be adversely affected (FME 2014).

In an assessment of African cities' capacity to adapt to climate change, Nigeria as a country was ranked 157 out of 192 countries for overall vulnerability based on exposure, sensitivity, ability to adapt, human habitat, and governance readiness (Leal Filho et al. 2018). The ND-GAIN index ranked Nigeria slightly higher, at 127 for vulnerability, but the ranking fell to 148 due to low readiness.

The adaptation gap is the difference between the level of adaptation action in progress and the anticipated needs given the projected climate change impacts. The African Adaptation Initiative's discussion paper from 2018, Enhancing Action on Adaptation in Africa, found that Nigeria is one of the countries with the highest gaps, over $90 \%$.

An analysis by IIED (Satterthwaite et al. 2018) for the 2018 Cities and Climate Change Science Conference assessed likely impacts of climate change specifically on urban populations living in informal settlements and working in the informal economy. This covers a range of climate change impacts that are observed for Nigeria and therefore is relevant to the waterfront communities of Port Harcourt. With higher maximum temperatures, the report notes that the high density, lack of open space, poor ventilation, and corrugated roofs of many informal settlements could contribute to even higher indoor temperatures in these communities. Many informal settlements are in areas at high risk of flooding. These risks are increased by projected intensifications of precipitation. Low-lying waterfront communities in Port Harcourt are clearly particularly vulnerable, and poor quality housing and lack of insurance exacerbate the impact in such communities.

The main outcome of that conference was the Global Research and Action Agenda on Cities and Climate Change Science which highlighted informality as one of six key research gaps as well as the importance of coproducing this knowledge to fill these gaps (World Climate Research Programme 2019). This chapter aims to contribute to the knowledge gap of informality and climate change action as well as the recommendation for the co-production of knowledge as the methodology of the paper, cowritten by community members of the Chicoco Collective with international experts and based on local data collection and global sources reflects this approach. 


\section{Climate Change Adaptation: Voices from the Community and Global Recommendations}

\section{Global Recommendations for Advancing Adaptation}

Adaptation, especially in cities and developing countries, has increasingly become a focus of international organizations and academia, which has resulted in the production of recommendations, guidelines, and priority areas for action.

The recent report Adapt Now: A Global Call for Leadership on Climate Resilience from the Global Commission on Adaptation states that a revolution is needed in three areas to advance adaptation action: understanding, planning, and finance. As part of the revolution on understanding, a better understanding of risks, solutions, and increased knowledge is cited.

In the report's chapter on cities, the main recommendations for the way forward are (1) mainstream information on climate risks in the planning and delivery of urban services, while strengthening local capacity; (2) harness the power of nature to respond to both water and heat risks; (3) build climate resilience by upgrading living conditions in vulnerable communities and informal settlements, drawing on community knowledge; and (4) increase climate-resilient investments and capture value from adaptation benefits (GCA 2019).

An in-depth analysis of several cities around the world and their adaptive capacity determined that cities should focus on the following: the need to prioritize actions, the importance of proper planning, the need for an integrated approach that takes into account structural and development issues, and emphasis on the poorer and more vulnerable communities (Leal Filho et al. 2019).

There has also been an increasing recognition internationally of the need to focus specifically on small and medium-sized cities; however, in a study of European cities, it was found that larger and more prosperous cities are the ones engaged in climate planning, whereas vulnerable cities are less engaged (Reckien et al. 2015). Although the study focused on Europe, the situation in Africa is likely the same and perhaps more so, however data and analysis on this is scarce.

There is not only a discrepancy between types of cities but also on the inequalities within cities and how this affects adaptation. The World Resources Institute (WRI) (2018) highlighted that "[c]ities around the world can thrive when they invest in climate-resilient infrastructure, information management system and riskreduction programs. But, most often residents who live in risk-prone areas are often left out of the planning and implementation process, leaving them even more vulnerable."

This report highlights that reducing vulnerability is not only about reducing exposure to hazards but also includes a socio-political aspect. Findings from the Urban Community Resilience Assessment program highlight the importance of social cohesion to increase individual and community resilience. This is one reason why relocation can be so damaging to resilience levels. Poor access to information communication systems for early warning and awareness of risks has also been shown to lower resilience (WRI 2018). 
Given the importance of public awareness, a report by BNRCC (2011) revealed that the level of public awareness on issues related to climate change in Nigeria is considered to be low. Inadequate information is considered to be one of the key constraints encountered in adapting to climate change in Africa (Otitoju and Enete 2016). Anabaraonye et al. (2019) recommend that information and knowledge about climate change, its causes, and its impacts, as well as mitigation and adaptation strategies, should be made available in simplified, more accessible, forms and translated into local languages. Other technological tools and platforms, such as mobile phone applications and social media, should be utilized in improving information literacy, access to information, and awareness creation (Ayanlade et al. 2017; Duru and Emetumah 2016).

These reports and recommendations suggest some key areas of action that a city like Port Harcourt and organizations like CMAP and the Chicoco Collective could focus on to initiate and strengthen climate change mitigation and adaptation measures, principally: (1) increase understanding about climate change through both the collection and dissemination of locally relevant data and information; (2) carry out long-term and integrated planning; (3) build the local capacity of diverse stakeholders; and (4) prioritize vulnerable communities living in waterfront communities.

Unfortunately, despite the risks and vulnerabilities and the clear need for adaptation measures in Nigeria broadly and Port Harcourt specifically, actions to date have been limited. The reality on the ground presents many challenges to effective action. However, building on the overview of CMAP's work above, the next two sections will further explore the perspectives of local communities and then summarize how the work of CMAP, Chicoco Collective, and local communities can provide a basis for effective action.

\section{Port Harcourt in Focus: Climate Change Adaptation Awareness and Action}

The Chicoco Collective devised and conducted a focus group research program to establish a baseline understanding of local perceptions of climate change impacts and adaptation approaches undertaken at the household and community level.

The sessions offered rich insights into local knowledge of climate change, and the various adaptation methods already adopted by informal waterfront communities. The following focus group questionnaire was created to guide the discussion.

\begin{tabular}{l|l|l|l|l}
\hline Topic & $\begin{array}{l}\text { Primary } \\
\text { question }\end{array}$ & $\begin{array}{l}\text { Secondary } \\
\text { question }\end{array}$ & $\begin{array}{l}\text { Tertiary } \\
\text { question }\end{array}$ & $\begin{array}{l}\text { Other } \\
\text { question }\end{array}$ \\
\hline $\begin{array}{l}\text { Climate change } \\
\text { awareness }\end{array}$ & $\begin{array}{l}\text { Have you heard } \\
\text { about climate } \\
\text { change? }\end{array}$ & $\begin{array}{l}\text { What have } \\
\text { you heard } \\
\text { about }\end{array}$ & & \\
\hline
\end{tabular}




\begin{tabular}{l|l|l|l|l}
\hline Topic & $\begin{array}{l}\text { Primary } \\
\text { question }\end{array}$ & $\begin{array}{l}\text { Secondary } \\
\text { question }\end{array}$ & $\begin{array}{l}\text { Tertiary } \\
\text { question }\end{array}$ & $\begin{array}{l}\text { Other } \\
\text { question }\end{array}$ \\
\hline & $\begin{array}{l}\text { climate } \\
\text { change? }\end{array}$ & & \\
& $\begin{array}{l}\text { What do you } \\
\text { know about the } \\
\text { impacts of } \\
\text { climate } \\
\text { change? }\end{array}$ & & & \\
\hline Effects of climate change & $\begin{array}{l}\text { Have there } \\
\text { been changes } \\
\text { in your } \\
\text { community or } \\
\text { city that you } \\
\text { can attribute to } \\
\text { climate } \\
\text { change? }\end{array}$ & $\begin{array}{l}\text { If yes, what } \\
\text { are the } \\
\text { impacts? }\end{array}$ & $\begin{array}{l}\text { If no, have you } \\
\text { experienced } \\
\text { extreme heat or } \\
\text { cold, flooding, } \\
\text { changes in } \\
\text { rainfall, more } \\
\text { extreme } \\
\text { storms, etc.? }\end{array}$ & \\
\hline Adaptation & $\begin{array}{l}\text { Are you or } \\
\text { your household } \\
\text { doing anything } \\
\text { to adapt to the } \\
\text { impacts of } \\
\text { climate } \\
\text { change? If yes, } \\
\text { please explain. } \\
\text { If no, why not? }\end{array}$ & $\begin{array}{l}\text { What about } \\
\text { your } \\
\text { community? }\end{array}$ & $\begin{array}{l}\text { Is the } \\
\text { government } \\
\text { doing } \\
\text { anything? }\end{array}$ & \\
\hline $\begin{array}{l}\text { Can you think } \\
\text { of any } \\
\text { solutions to } \\
\text { adapt to the } \\
\text { impacts of } \\
\text { climate } \\
\text { change? }\end{array}$ & $\begin{array}{l}\text { At the } \\
\text { household } \\
\text { scale? }\end{array}$ & $\begin{array}{l}\text { Community } \\
\text { scale? }\end{array}$ & $\begin{array}{l}\text { Government } \\
\text { scale? }\end{array}$ \\
\hline Solutions & & & \\
\hline
\end{tabular}

The focus group sessions were staged in three different parts of the city. Another session was held for members of the various Chicoco programs. The Chicoco cohort is drawn from waterfront communities across the city. Five men and five women of the Chicoco cohort were randomly selected to participate in that session. Focus group sites were selected to achieve a cross section of neighborhood types and to capture a holistic range of experience across age, socio-economic status, ethnicity, and location. Two communities were chosen from the Old Port Harcourt Township, one of the older colonial areas of the city, which is ringed by over half of, and some of the oldest, waterfront communities in the city. One community was selected from the Diobu axis of Port Harcourt, which is home to over 20 waterfront communities. These communities were selected based on their diverse situations, but also due to existing knowledge of and relationships with community leadership, which facilitated access. Importantly, each of the communities is also host to some aspect of the informal oil and gas industry. The discussions were held in a community space, either a town hall or central area in each community, and participants were recruited 


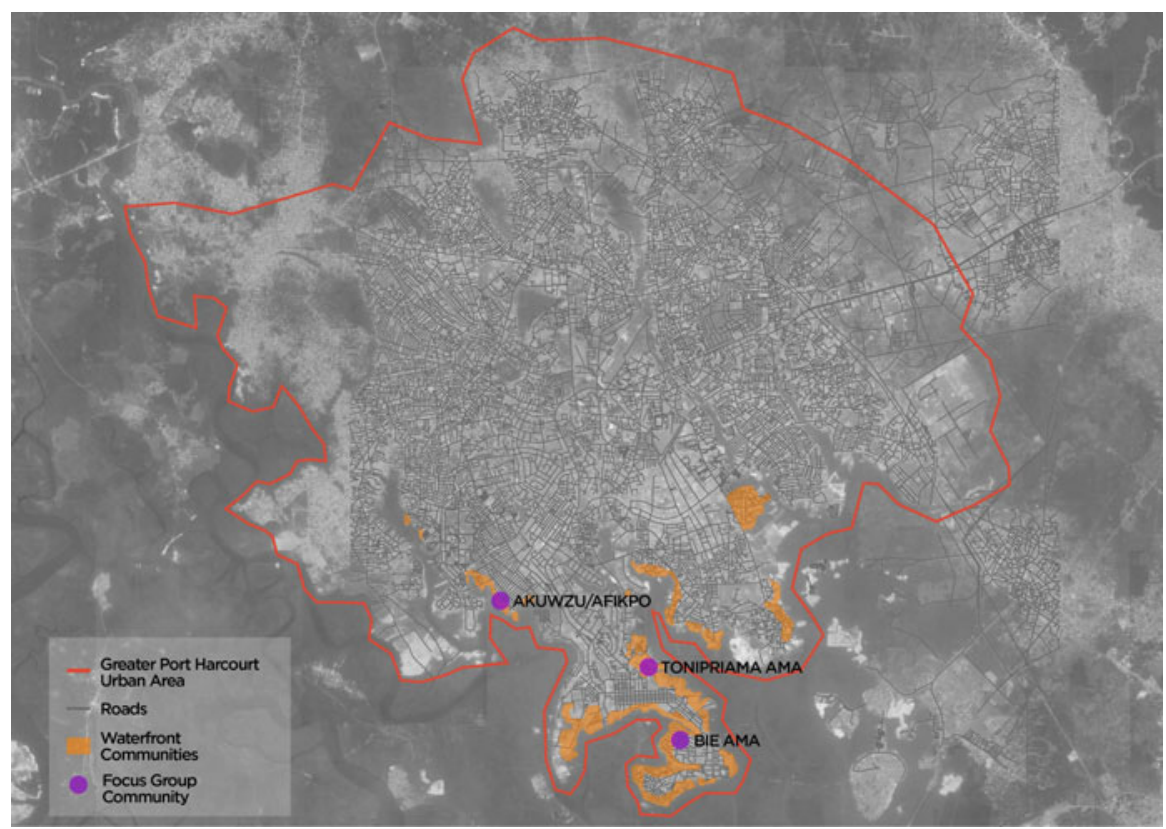

Fig. 10 Map of the greater Port Harcourt highlighting waterfront communities and selected focus group community locations (created by CMAP in March 2020 using QGIS and data from Rivers State Office of the Surveyor General)

with the help of community leadership to include a mix of men and women. A map of Port Harcourt highlighting the focus-group communities can be seen below (Fig. 10).

Akwuzu/Afikpo is a low-income waterfront community in the Diobu area established over 40 years ago. Entrance to the community is through a community market at the top of a steep laterite slope. The community is only accessible by pedestrians on poorly maintained concrete steps. The community has had minimal government-led interventions and minimal community provision of drainage systems, security, schools, and toilet facilities or potable drinking water. Along with other waterfront communities in the Diobu axis, in 2009, Akwuzu/Afikpo was faced with the threat of demolition. Many residents of the community are actively involved in the fishing industry. The community is also a major hub for oil bunkering activities, also known as kpo-fire. The area is predominantly occupied by Kalabari people.

Ten people, five men and five women, attended the focus group session in Akwuzu/Afikpo: the community chief, four fishermen/women, two higher institution students, a retired nurse, and two traders.

Bie Ama Community is a mixed middle- and low-income community in the Old Port Harcourt Township located on a reclaimed wetland area. Bie Ama is made up of five smaller communities or "polos" and is predominantly occupied by Okrikan people. Bie Ama is popularly known as New Road in Borokiri and was established 
on a sand-fill project in the early 1980s. This community has over 800 structures and has been developed with some regard to a layout plan. It is comprised primarily of cement block structures with aluminum, asbestos, and zinc roofing materials. The community has several churches and a mix of private nursery, primary and secondary schools. Residents include civil servants, teachers, artisans, traders, and contractors. As a waterfront community, the trading of illegally refined or bunkered products is prevalent.

Ten people, seven men and three women, participated in the focus group: two medical doctors, the community youth leader, two bunkerers (workers in the informal oil sector), a retired Nigerian national petroleum company worker, the former Radio Rivers/Nigerian Tide managing director, the female community leader, and two traders.

Tonipriama Ama is the host community of the Chicoco Collective. This waterfront community is comprised of seven smaller communities or "polos." It is predominately occupied by Okrikan people and has existed for over 60 years. This community has over 2,000 structures, constructed from a mix of concrete block and less durable materials such as zinc or wood. The community has a busy commercial dock that is a hub for ferries, fishermen, and oil bunkering boats. There are also several marine companies located in the community. The community has had several government interventions, including the paving of several access roads and the construction of a private government jetty. There are two roads running through the community, and it is easily accessible by motor vehicle. There is one major community public toilet facility and several public boreholes.

The Tonipriama session also comprised ten participants, four women and six men: the Ama (the collective administrative unit containing the polos) chairman, four traders, a teacher, two fishermen, a bunkerer, and a student.

In the focus groups, participants were first asked if they had heard of climate change and what they understood by the term and of the phenomenon. Responses evidenced a general familiarity with the term and an understanding that climate change is related to changing weather conditions and caused by humans. Despite some familiarity with the term climate change, it was evident that many respondents used the phrase to describe any environmental issue, without a clear understanding of the differentiation between degradation (air quality issues, water pollution, etc.) and changes in climate (changes in precipitation, flooding, increased temperature, etc.).

\section{Climate Change Impacts Observed}

All of the communities shared experiences that they attributed to climate change and the sense that its impacts are felt citywide, increasing in intensity and frequency. Heat and flooding (both from sea level rise and excessive rainfall) were raised across groups as an observable impact of climate change, popular perceptions aligning with current scientific research on impacts of climate change in Nigeria. 
Food insecurity and hunger, as a result of food scarcity, increased food prices, difficulty of farmers to predict the weather for planting seasons, scarcity of seafood due to decrease in catch or the catching of dead fish, and food storage and spoilage issues were raised by all groups. More research is needed to ascertain what links, if any, these issues have to climate change. However, these are clearly primary concerns for communities and should be addressed in adaptation and/or development research and action.

Health issues were also raised by all groups: Disease burden increase, with measles and chicken pox cited specifically, rashes, dehydration, respiratory issues, cancer, and eye conditions were all perceived by participants as being linked to climate change. While such attribution is far from clear for all the conditions mentioned, connections to air pollution seem to be a reasonable assumption, and it is likely that the dehydration and rash conditions are related to heat and/or water quality and access. More research would be needed to confirm such links. Nevertheless, it is clear that here too, adaptation and development measures would need to address community-identified health priorities.

The issues of pollution and environmental degradation were another focus of all groups. The black soot crisis has gained citywide attention recently, and this was reflected in the group discussions. The toxicity of rainwater, rendering it unusable for consumption or cooking, was mentioned by many. Marine habitat pollution and its impact on fish stocks were another commonly voiced concern for waterfront communities with members who still depend directly on aquatic urban ecosystems for their livelihoods. Again, while air and water quality may be linked to climate change-driven dynamics, not all of these issues are necessarily directly attributable to climate change. Nevertheless, it is likely that climate change exacerbates these problems. It is clear that environmental degradation is a major concern and in Port Harcourt the drivers of climate change are the same causes of environmental degradation. Therefore both mitigation and adaptation efforts should address these environmental issues.

Other issues raised in different groups, relating to migration, cost of living increases, and security, may involve interesting direct or indirect relationships to climate change. For instance, migration is a much researched topic in this connection, but more area-specific data would need to be gathered to determine causality and appropriate adaptation actions.

\section{Adaptation Actions}

As the effects of the climate crisis intensify, residents of Port Harcourt have developed different coping techniques for them. The participants of the focus group highlighted some of the ways they or their neighbors are changing their behavior. For increased heat and rising temperatures, coping techniques included: bathing with cold water three to four times a day, showering multiple times at night, and sleeping outside till late in the night to get some cooler air before going indoors and then sleeping on relatively cool mud or stone floors. 
Increases in water intake to mitigate dehydration caused by the heat have significant financial impacts on households that spend disproportionately high proportions of their income on food and water essentials. Participants reported that water is also used to keep food cool and to slow its spoiling in the absence of reliable power for refrigeration. Other practices of drying food with salt were also emphasized as a way to preserve their food and kill pests, such as worms. Additionally, as a result of increased food prices, some respondents say that they are eating only once a day. Self-rationing is increasingly common.

Adaptation methods to address flooding include improving waste management by methods such as establishing more designated dumping sites to discourage people from throwing waste in waterways. Other discussed methods included community gutter cleaning efforts, construction of high tables to store personal belongings, blocks to raise beds, and raised doorsteps to prevent water ingress.

Respondents discussed their discomfort with and concern for the black soot air quality crisis facing their city. Concern for their health has prompted some to start wearing facemasks on days when air quality was visibly bad. The wearing of facemasks was practiced before the recent coronavirus pandemic.

Despite being asked about their adaptive practices, several of the responses were not necessarily relevant as adaptation measures, but really more about other impacts related to a changing climate, particularly increasing temperatures. Many focus group participants brought up the issue of increased lethargy and unproductivity at work from the higher temperatures. Others mentioned the need to increase their use of generators, which although not explicitly said, is likely related to needing to run fans.

It is clear that most adaptation efforts are at an individual level or household level. Knowledge of adaptive practices at community or broader scale was quite limited. But, as noted in the findings from the fecal sludge management study, some communities are undertaking collective adaptation actions, such as managing flooding issues in a coordinated manner with berms and nets. It is unclear as to whether focus group participants are simply unaware of any actions that their community or the government may be undertaking or whether they are not able to relate any actions specifically to a response to a changing climate. This highlights the need for more awareness raising of potential adaptation actions as well as planning for more coordinated efforts.

One of the communities is making efforts to curb issues of poor sanitation and dumping by discouraging the act of disposing waste in waterways by fining offenders. Two of the communities have active community leadership committees and subcommittees in charge of sanitation, and community electricity and light, among other specialized issues. These committees are tasked with maintaining community infrastructure and solving challenges that arise in the community by enacting rules and regulations, sometimes including fines or punishments for breaking these rules, or introducing levies to construct new infrastructure. Tonipriama Ama, for example, has been charging for use of and maintaining a public toilet, and likewise through its light committee, has organized levies to replace light poles and broken transformers. Although currently these committees have not addressed impacts directly related to a changing climate, these initiatives demonstrate a capacity to develop and deploy adaptations at community level. 


\section{Proposed Adaptation Solutions}

When asked about other potential solutions for addressing climate change, the participants highlighted the need for education, behavior change, infrastructure projects, and government intervention. They proposed that, to tackle the effect of the climate crisis, government and relevant stakeholders needed to be more responsive, accountable, and active. They criticized lack of action, insufficient resourcing, and lack of human and technical capacity. Government and relevant stakeholders were urged to lead sensitization efforts and to provide basic amenities. There was a clear understanding of interplay between behavior and infrastructure. For example, on the one hand, the need for changed waste dumping practices, particularly regarding waterways, and for waste disposal practices that facilitate recycling and reuse was recognized. On the other hand, groups also stressed the need for better waste management systems including the placement of proper disposal containers within the communities and the construction of better gutters and drainage systems.

Groups proposed awareness-through-action and learning-by-doing approaches, as well as the need for more active community debate. Tree planting and community town hall programs were mentioned in this connection. Community sanitation exercises - the mobilization of the entire community to clean streets, drains, and public spaces - were also mentioned. Indeed, this capacity to mobilize, en masse, as a community is one of the significant resources that such settlements can draw on.

Energy was a perennial topic of debate. Gas flaring has long been a highly visible example of the violent environmental externalizations of the hydrocarbon economy in the Niger Delta. People linked the demand to end flaring with the desire to transition to renewable energy. Respondents wanted to see oil and gas companies halt polluting activities and proposed "trapping" carbon emissions. The technical approaches to doing so were not detailed. Security forces tasked with policing the informal oil industry often spill confiscated hydrocarbon products directly into waterways or set them ablaze. Respondents voiced strong opposition to these practices and proposed that, instead, confiscated product should be taken to official refineries. The retraining of bunkerers and the regulation of the informal economy to improve the environmental standards of operations were also proposed. While these are not strictly adaptation efforts, they can be considered as modest mitigation efforts and community actions aimed at a cleaner community environment.

\section{Conclusions and Recommendations}

Port Harcourt and many other cities in Africa face a multitude of climate change, environment and development challenges. These challenges are greatest in informal settlements. As informality is the dominant mode of African urbanism, it is critical that interventions respond to the situated constraints and potentials of informality and how it is variously manifested in communities and neighborhoods across the continent. To date, climate change adaptation has not necessarily been a priority in and for informal urban settlements. Many of the requirements for effective action - 
from data to finance - are often lacking. Too often, the priorities, knowledge, skills, and participation of local residents themselves are missing from external interventions. However there is growing awareness of the problems and initial steps and information that can be built upon for effective solutions. Below are recommendations drawn from the experience of CMAP, Chicoco, and the waterfront communities in Port Harcourt. As the formulation of these recommendations has been led by residents and through partnership with international experts, we hope they might serve as a basis for mobilization and action in other African cities facing similar constraints and opportunities.

- Awareness and local knowledge. There is a of lot consistency between scientific findings on the impacts of climate change in Nigeria and those observed and recorded in local focus groups. This suggests that, while innovation is needed in the popular dissemination of research findings, many residents in informal settlements may not be aware of the latest research on climate change, they are acutely aware of direct impacts from their own lived experience and are developing local adaptations. This experience, critical awareness, and approach to situated adaptation are a potentially valuable asset for climate change response efforts.

- Building awareness through local methods. International organizations and governments should draw on locally established information sharing and storytelling initiatives and networks. Chicoco Radio and Chicoco Maps' Encounter and Exchange program are examples of the potential of community media and action programs not only to raise awareness and strengthen networks locally, but also to catalyze citywide dialogue. The roadshows, concerts, town hall listening clubs, broadcasts, and live discussion programs that were part of Chicoco's first radio drama season successfully stimulated citywide debate around issues of forced evictions and police brutality. Such a platform could easily be mobilized for climate change adaptation and environmental justice issues.

- Inclusive data and knowledge collection and sharing. There is a need for more institutional investment in knowledge and data gathering efforts on climate change impacts in Nigeria at the national and local levels. To collect and disseminate knowledge and data relevant to informal urban settlements in Nigeria, residents of those settlements need to be successfully involved. The deep, detailed, accurate, and appropriate datasets gathered by the young Chicoco Maps team with CMAP's support demonstrate a successful methodological approach to, and effective methods of, participatory data gathering and sharing in Nigeria's informal settlements. This participatory, partnership-based approach can be mobilized in a more focused way on climate change research and the development of sustainable local adaptations.

- Integrated solutions and local context. Adaptation solutions need to tackle development and environmental justice issues alongside climate change adaptation action, especially health issues. It is also important to recognize the context of the local economy - both formal and informal. In the case of Port Harcourt, this includes reckoning with the economic domination of the oil and gas industry. 
- Small and local efforts can be compounded for larger impact. Some routes to scale involve a concert of small-scale interventions. CMAP and Chicoco Maps' citywide sanitation research found that the solution to Port Harcourt's sanitation crisis is not a billion-dollar central sewerage system. Rather, onsite community solutions, manageable at neighborhood-level and network-scalable, offer a sustainable approach through which many small actors can coordinate to achieve scale. As found in the focus groups, individuals and households will take adaptive measures that can be effective for reducing loss and vulnerability.

- Large-scale responses are also necessary, with community involvement and input. Local communities have devised some effective individual or neighborhood-level adaptation techniques, but larger infrastructure interventions, requiring access to significant capital and technologies, are necessary. Yet, for these solutions to achieve sustainability, they nonetheless need to engage and involve community actors. In a city like Port Harcourt, where the government suffers a deep trust deficit, large-scale interventions often fail because of a lack of local cooperation or even active resistance. The trust and involvement of community actors is crucial to large-scale climate change responses, particularly as largescale behavior changes and cultural shifts are necessary for success.

- Bottom-up collaboration to build accountability. A bottom-up approach follows from the previous recommendation. While community members have raised the need for government intervention and effective government service provision, heavily top-down approaches to external interventions in communities with already strained relationships with their representatives are going to be difficult. Involving communities, not merely in consultation exercises, but actively in project design, is key. This is likely both to increase the appropriateness of adaptation measures, and importantly, to build a robust demand for duty bearer accountability. Demand-side platforms for accountability for climate change action in cities like Port Harcourt are critical to counter a culture of flourishing impunity that has allowed staggering environmental degradation and unsustainable exploitation to go unchecked for decades.

Acknowledgments In-kind financial support was provided by the Chicoco mapping team for research, data collection and analysis, and the focus group discussion support team, namely the recording technician, George Sosipiriala, and community engagement specialist, Fubara Tokuibiye Samuel. Michael Uwemedimo, Ana Bonaldo, and the rest of the CMAP team also provided in-kind support and guidance for this chapter.

\section{References}

African Adaptation Initiative (2018) Enhancing action on adaptation in Africa. Discussion paper for Africa state of adaptation report

Akande A, Costa AC, Mateu J, Henriques R (2017) Geospatial analysis of extreme weather events in Nigeria (1985-2015) using self-organizing maps. Adv Meteorol 2017(2):1-11

Amanchukwu RN et al (2015) Climate change education in Nigeria: the role of curriculum review. Education 5(3):71-79 
Anabaraonye B et al (2019) Educating farmers and fishermen in rural areas in Nigeria on climate change mitigation and adaptation for global sustainability. Int J Sci Eng Res 10(4):1391-1398

Ayanlade A et al (2017) Comparing smallholder farmers' perception of climate change with meteorological data: a case study from southwestern Nigeria. Weather Climate Extremes $15: 24-33$

Bloch R, Monroy J, Fox S, Ojo A (2015) Urbanisation and urban expansion in Nigeria. Project report. ICF International, London

BNRCC (Building Nigeria's Response to Climate Change) (2011) National adaptation strategy and plan of action on climate change for Nigeria (NASPA-CCN). Prepared for the Federal Ministry of Environment Special Climate Change Unit

Collaborative Media Advocacy Platform (CMAP) (2018) Ibiapu Polo, Amatari Polo, and Darick Polo. Household Survey Data Summary Report

Dioha MO, Emodi NV (2018) Energy-climate dilemma in Nigeria: options for the future. IAEE Energy Forum 2018(2):29-32

Duru NP, Emetumah CF (2016) Evaluating the effects of information literacy on climate change awareness among students in Imo State University. Arch Current Res Int 4(3):1-10

Ebele NE, Emodi NV (2016) Climate change and its impact in Nigerian economy. J Sci Res Rep 10 (6): $1-13$

Elisha I et al (2017) Evidence of climate change and adaptation strategies among grain farmers in Sokoto State, Nigeria. IOSR J Environ Sci Toxicol Food Technol (IOSR-JESTFT) 11(3):1-7

Federal Ministry of Environment (FME) (2014) United Nations climate change Nigeria. National Communication (NC). NC 2. 2014

Global Commission on Adaptation (2019) Adapt now: a global call for leadership on climate resilience, Washington, DC

IPCC (2014a) Summary for policymakers. In: Field CB et al (eds) Climate change 2014: impacts, adaptation, and vulnerability. Part A: global and sectoral aspects. Contribution of working group II to the fifth assessment report of the intergovernmental panel on climate change field. Cambridge University Press, Cambridge/New York, pp 1-32

Leal Filho W et al (2018) Strengthening climate change adaptation capacity in Africa-case studies from six major African cities and policy implications. Environ Sci Pol 86:29-37

Leal Filho W, Balogun AL, Olayide OE et al (2019) Assessing the impacts of climate change in cities and their adaptive capacity: towards transformative approaches to climate change adaptation and poverty reduction in urban areas in a set of developing countries. Sci Total Environ 692:1175-1190

Matemilola S (2019) Mainstreaming climate change into the EIA process in Nigeria: perspectives from projects in the Niger Delta region. Climate 7(2):29

Nigerian Conservation Foundation (2008) Climate change. http://www.ncfnigeria.org/component/ content/article/90-programmes/127-Climate-Change. Accessed Mar 2020

Odemerho FO (2014) Building climate change resilience through bottom-up adaptation to flood risk in Warri, Nigeria. Environ Urban 27(1):139-160

Odjugo PA (2005) An analysis of rainfall patterns in Nigeria. Glob J Environ Sci 4(2):139-145

Odjugo PAAO (2009) Quantifying the cost of climate change impact in Nigeria: emphasis on wind and rainstorms. J Hum Ecol 28(2):93-101

Odjugo O (2010) General overview of climate change impacts in Nigeria. J Hum Ecol 29(1):47-55

OECD/SWAC (2020) Africapolis (database), www.africapolis.org. Accessed 11 Feb 2020

Ofoegbu C, Chirwa PW (2019) Exploring the potential for green growth uptake in the South African forest sector. Reg Environ Chang 19(5):1469-1480

Ojomo E, Elliot M, Amjad U, Bartram J (2015) Climate change preparedness: a knowledge and attitudes study in southern Nigeria. Environment 2(4):435-448

Omoruyi EP, Kunle OA (2012) Effects of climate change on health risks in Nigeria. Asian J Bus Manag Sci 1(1):204-215

Otitoju MA, Enete AA (2016) Climate change adaptation: uncovering constraints to the use of adaptation strategies among food crop farmers in South-west, Nigeria using principal component analysis (PCA). Cogent Food Agric 2(1):1-11 
Reckien D, Flacke J, Olazabal M, Heidrich O (2015) The influence of drivers and barriers on urban adaptation and mitigation plans - an empirical analysis of European cities. PLoS One 10(8):1-21

Satterthwaite D, Archer D, Colenbrander S, Dodman D, Hardoy J, Patel S (2018) Responding to climate change in cities and in their informal settlements and economies. Consultant report presented at the IPCC international scientific conference on cities and climate change, Edmonton. International Institute for Environment and Development, London

Theis M, Lloyd-Jones T, Adenekan S, Gusah S, Moor M, Mulyawan B, Gusah D (2009) Port Harcourt waterfront urban regeneration: scoping study. Project Report. MLC Press, Max Lock Centre, University of Westminster, London

World Bank (2016) From oil to cities: Nigeria's next transformation. Directions in development. World Bank Group, Washington, DC

World Bank (2017a) Sustainable WSS services in Nigeria (Vol. 2): Data collection report (English). World Bank Group, Washington, DC

World Bank (2017b) Sustainable WSS services in Nigeria: fecal sludge management - a practical guide for evaluating needs and developing solutions (English). World Bank Group, Washington, DC

World Climate Research Programme (2019) Global research and action agenda on cities and climate change science - full version. In: Prieur-Richard AH, Walsh B, Craig M, Melamed ML, Colbert M, Pathak M, Connors S, Bai X, Barau A, Bulkeley H, Cleugh H, Cohen M, Colenbrander S, Dodman D, Dhakal S, Dawson R, Espey J, Greenwalt J, Kurian P, Lee B, Leonardsen L, Masson-Delmotte V, Munshi D, Okem A, Delgado Ramos GC, Sanchez Rodriguez R, Roberts D, Rosenzweig C, Schultz S, Seto K, Solecki W, van Staden M, Ürge-Vorsatz D (eds) WCRP Report No. 3/2019, 31pp

World Health Organization (2015) Climate change and health: country profile. United Nations Framework Convention on Climate Change, Nigeria

World Resources Institute (2018) Prepared communities: implementing the Urban Community resilience assessment in vulnerable neighborhoods in three communities, Washington, DC

Open Access This chapter is licensed under the terms of the Creative Commons Attribution 4.0 International License (http://creativecommons.org/licenses/by/4.0/), which permits use, sharing, adaptation, distribution and reproduction in any medium or format, as long as you give appropriate credit to the original author(s) and the source, provide a link to the Creative Commons license and indicate if changes were made.

The images or other third party material in this chapter are included in the chapter's Creative Commons license, unless indicated otherwise in a credit line to the material. If material is not included in the chapter's Creative Commons license and your intended use is not permitted by statutory regulation or exceeds the permitted use, you will need to obtain permission directly from the copyright holder.

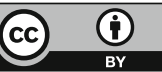

